Tarih Kültür ve Sanat Araştırmaları Dergisi

Revue des Recherches en Histoire Culture et Art

مجلة البحوث التاريخية والثقافية والفنية
Vol. 6, No. 3, June 2017

Copyright (C) Karabuk University

http://kutaksam.karabuk.edu.tr

\title{
DOI: 10.7596/taksad.v6i3.917
}

Citation: Beyaz, Ç., Mercan, Ö., Anıl, G., \& Okutan, H. (2017). Konut Transformasyonu Bağlamında Lefke'deki CMC Evlerinin Zaman İçerisindeki Dönüşümü. Journal of History Culture and Art Research, 6(3), 713-738. doi:http://dx.doi.org/10.7596/taksad.v6i3.917

\section{Konut Transformasyonu Bağlamında Lefke'deki CMC Evlerinin Zaman İçerisindeki Dönüşümü \\ The Gradual Transformation of CMC Houses in Lefke within the Context of Housing Transformation}

\author{
Çağla Beyaz ${ }^{1}$, Özge Mercan ${ }^{2}$, \\ Gaye Anıl ${ }^{3}$, Hilmi Okutan ${ }^{4}$
}

\begin{abstract}
This study aims to determine the reflections of the factors affecting the gradual change of the houses constructed for the American mining company CMC (Cyprus Mines Corporation) in Lefke between 1916 and 1974. Research has shown that such factors as life standards, needs, politics, environmental factors, climate, geography and cultural factors have changed the housing demand. Having taken all these factors into consideration, we have reached a conclusion regarding the transformation of the houses by analysing the collected data by field research techniques appropriate to CMC houses in Lefke. The field research has been conducted by taking samples from each category and analysing them; and the gradual transformation and the underlying environmental factors have been determined. The field research techniques used in the study are interviews, photos, relieves and archive research.

In the result obtained from the general work; Along with the rapid development caused by the effects of the Industrial Revolution, religious, cultural, economical, political and architectural conditions have been shaped in different forms and values. Along with these circumstances, the changes and transformations that observed in the world and affecting the cities have also affected Cyprus Island. In the Lefke region, along with the establishment of the CMC, the positive and negative effects of the terraced houses, built for the first time in Cyprus in four different categories and their close surroundings, draw quite attention. In the study, the transformations of these houses until today and the factors affecting them have been also determined.
\end{abstract}

Keywords: CMC, CMC houses, Structural transformation, Interior space.

\footnotetext{
${ }^{1}$ Yakın Doğu Üniversitesi, Mimarlık Fakültesi, İç Mimarlık Bölümü, Kıbrıs. E-mail: cagla.beyaz@neu.edu.tr

2 Öğretim Görevlisi, Yakın Doğu Üniversitesi, Mimarlık Fakültesi, İç Mimarlık Bölümü, Kıbrıs. E-mail: ozge.atamer@neu.edu.tr

${ }^{3}$ Öğretim Görevlisi, Yakın Doğu Üniversitesi, Mimarlık Fakültesi, İç Mimarlık Bölümü, Kıbrıs. E-mail: gaye.anil@neu.edu.tr

${ }_{4}^{4}$ Öğretim Görevlisi, Yakın Doğu Üniversitesi, Mimarlık Fakültesi, İç Mimarlık Bölümü, Kıbrıs. E-mail: hilmi.okutan@neu.edu.tr
} 


\section{Öz}

Çalışma, Lefke Bölgesinde 1916-1974 yılları arasında faaliyet gösteren Amerikan maden şirketi CMC (Cyprus Mines Corporation) için yapılmış olan konutların zaman içerisindeki form değişimine etki eden faktörlerin, konut mekânına olan etkilerini saptamaya yöneliktir. Konut ihtiyacının, yaşam şartlarına, ihtiyaca, siyasete, çevresel faktörlere, iklime, coğrafyaya, kültürel etkenlere göre form değiştirdiği yapılan araştırmalarda görülmektedir. Tüm bu etkenlerin 1şı̆̆ında, Lefke Bölgesi, CMC evleri özelinde uygun tekniklerle yapılan alan çalışmasından elde edilen verilerin biraraya getirilmesiyle, konutların dönüşümü ortaya konmuştur. Yapılan alan çalışması için, her kategoriden birer örnek ele alınarak analizi yapılmış, zaman içerisindeki dönüşümü ve bu dönüşümlere etki eden çevresel faktörler tespit edilmiştir. Alan çalışması kapsamında, tüm bu verilerin toplanması için gerekli olan görüşmeler, fotoğraf çekimleri, rölöve çıkarma ve arşiv araştırma teknikleri kullanılmıştır.

Çalışmanın genelinden elde edilen sonuçta; Endüstri Devrimi’nin etkisiyle oluşan hızlı gelişme ile birlikte dini, kültürel, ekonomik, siyasal ve mimari gibi koşullar farklı biçim ve değerlerle şekillenmiştir. Bu şekillenen koşullarla birlikte, dünyada gözlemlenen ve kentleri etkileyen değişim ve dönüşümler Kıbrıs Adası'nı da etkilemiştir. Lefke Bölgesi'nde, CMC'nin kurulmasıyla birlikte buna paralel dört kategoriden oluşan ve ilk kez teraslı olarak üretilen konutların ve onların yakın çevrelerinin, bölgeye olan olumlu ve olumsuz etkileri oldukça dikkat çeker. Bu konutların, günümüze gelene kadar olan dönüşümleri buna etki eden faktörler tespit edilerek sonuçlandırılmıştır.

Anahtar kelimeler: CMC, CMC evleri, Yapısal dönüşüm, İç mekan.

\section{I.GİRIŞ}

Araştırma, sanayileşmenin, kent dokusunu, konut oluşumu bağlamında nasıl değişikliğe uğramış olduğuyla ilgilidir. Çalışma kapsamında, Lefke bölgesinde 10 Mart 1916 yılında kurulan maden işletmesi olan CMC çerçevesinde, ilk etapta işçilerin barınması amacıyla oluşturulup çeşitlendirilen konutlar ve konutların etkisiyle düzenlenmiş kamusal mekanların, kente olan etkileri ele alınmıştır. CMC'nin 1974'te kapanmasının ardından konutların günümüze dek olan süreçteki değişimi, yapılan saha çalışmalarında elde edilen verilerle analiz edilecektir.

Yaşamın akışıyla birlikte ortaya çıkan değişiklikler insanların hayatlarında var olan fiziksel oluşumlara da etki eder. Konut, bu değişikliklerin yansıdığı fiziksel oluşumların başında yer alır. Bunun nedeni, konutun ihtiyaca yönelik bir yapı olmasının ötesinde, kültürel bir anlam biçimi olarak nitelendirilebilmesidir. Geleneksel kültürlerin zaman içerisinde değişmesine 
neden olan etkenler arasında, siyaset, din, kentleşme, sanayileşme ve bunlara bağl1 toplumların düşünsel yapısında oluşan değişikliklerden bahsedilebilir. Tüm bu etkenler, konutların dönüşümüne de neden olmaktadır.

Doğu Akdeniz bölgesinde bulunan Kıbrıs Adası, fiziksel konum özelliğinden dolayı 3000 yılı aşan bir süredir, Afrika, Anadolu, Avrupa ve Orta Doğu'dan gelenlerin uğrak yeri olmuştur (Bağışkan, 2013, pp. 4-5). Adanın iklimsel koşulları, stratejik konumu ve doğal kaynakları bu ilginin temelini oluşturmaktadır. Günümüze kadar süregelen toplumsal olaylar, kültürel çeşitlilik, ekonomik sıkıntılar, dış etkenlerle yaşam şartlarının form değiştirmesi ve sanayileşme, konutun da zamanla farklı biçimlere dönüşmesine neden olmuştur.

1900'lü yılların başında, Kıbrıs Adası'nın büyük bir bölümü kırsal olması nedeniyle tarım yönünden gelişmiş olsa da, nüfusu az olan kasabalarda küçük sanayiler kurulmuş olduğu yapılan araştırmalarda tespit edilmiştir. Halkın çoğunluğu kendi konut ve tarlalarına sahip olmasına rağmen, köylerden kasabalara ulaşım, yolların toprak olması nedeniyle zorlukla yapılmaktayd1. $\mathrm{Bu}$ nedenle kasap, terzi, tüccar gibi esnaflar bu köylere gidip hizmet götürmekteydiler (Beratl1, 2002, pp: 66).

Konut biçimlenişi, adanın bölgelerine göre değişiklik göstermektedir. Örneğin, standart çiftçi konutu dar ama uzun, dikdörtgen bir plana sahiptir. Giriş kapısı, ahşap ve hayvanların da kolaylıkla içeri girebilmesi için yaklaşık 180.00-200.00 m. ve iki kanatlı olarak yapılmaktadır. Zemin killi toprak ya da yerli mermer döşelidir. Tavanı düz ya da hafif eğimli, kil ile kaplıdır. Tüm yaşam tek bir oda içerisinde geçmektedir. Bu oda, geceleri hayvanların da barınağı olarak kullanılabilmekte, böylelikle ağıl yapmak için masraf yapılmasına gerek duyulmamaktadır. Yapılar, yazın serin, kışın ise 1lık olur. Su temini de, kuyulardan çekilerek yapılmaktadir.

Amerika menşeli bir maden şirketi olan CMC (Kıbrıs Maden Şirketi/Cyprus Mine Corporation)'nin Lefke Bölgesi’nde tespit edilen cüruf emareleri sayesinde, bölgede daha önceki dönemlerde de bakır madeninin olduğu bilinmektedir (Anıl, C. 2015, sözlü kaynak). Manganez değeri yüksek siyah renkli cürufların Roma dönemine ait oldukları düşünülürken, öte yandan demir değeri yüksek olan kırmızı-kahve renkli cürufların ise Fenikelilere ait olduğu tahmin edilir (Bağışkan, 2013, pp. 4-5). Lefke bölgesindeki eski dönemlerden kalma maden ocakları CMC tarafından çalıştırılmaya başlanmadan önce, firmanın yerli müdürü J.L. Bruce, antik dönemden kalma maden ocaklarını inceleyerek, analizlerini yapmış ve bu konudaki “The Swedish Cyprus Expedition” isimli kitabının III. cildine 'EK V' olarak bu analiz sonuçlarını eklemiştir (J.L. Bruce, 1937, pp. 205-232). Bu araştırma yazısında, Bruce, M.S 129-216 yılları arasında yaşamış olan Galen'in maden ocaklarının işletilmesiyle ilgili bilgilerine de yer vererek, 1912 yılından itibaren Lefke çevresindeki Aplıç, Fugassa Tepesi, 
Mavrovouni ve Skuriotissa'daki antik dönemlerden kalma maden ocakları ile birlikte diğer maden ocaklarını da arkeolojik yönden incelemiş olan Amerikalı maden mühendisi Charles Godfrey Gunter'in bilgilerinden de yararlanmıştır (Bağışkan, 2013) . Bakır yataklarının varlığı nedeni ile 10 Mart 1916 yılında Charles Young Ghunter, Mudd ve Wiseman adlı mühendisler ile birlikte adaya gelip Lefke Bölgesi'ndeki bu işletmeyi kurmuştur (Lavender, 1962). Maden şirketinin kurulması ile alanda çalışacak işçilerin barınma sorunlarını çözmek amacıyla 1922 yılında konutlar inşa edilmeye başlanmıştır. 1924 ylında ise, işçileri hasta eden sıtma (Malarya) hastalığının neticesinde üretim düşmüştür. Hastalığa neden olan bataklıkları kurutmak amacıyla kıyı boyunca efkalipto (okaliptüs) ağaçları ekilerek, Pendaya'ya (Yeşilyurt)da bir hastane inşaa edilmiştir.

1926 yılında, Xero'daki(Ksero) işçi evleri yapılır ve ardından 1928 yılında ise bu kez Karadağ'a (Mavrovouni) ikinci bir işçi köyü kurulur. Xero, Skuriotissa ve Karadağ'daki işçi evleri 1942 yılında Kuzey Afrika'da savaşmış olan İngiliz askerlerinin dinlenme kampı olarak kullanılmıştır. Ayrıca, II. Dünya savaşında Alman işgalinden kaçan birçok Yunanlının da CMC tesislerinde konakladı̆̆ı yapılan araştırmalarda karşımıza çıkmaktadır. CMC evleri yapılırken çalışanların statüleri ile medeni durumları dikkate alınmıştır. Bu nedenle bekâr işçi evleri, evli işçi evleri, ustabaşı (formen) evleri ve mühendis evleri olmak üzere dört ayrı konut tipi belirlenmiştir (Bağışkan, 2013). Adada ilk kez, dış mekanı da tasarlanmış bir toplu konut olma özelliğini taşıyan bu evlerin yapımı sayesinde yeni komşu köyler kurulmuştur (Dağlı, 1999, pp. 76-83).

Zaman içerisinde, kullanıcı ihtiyaçlarının değişimi, kültürel, siyasal, ekonomik ve sosyal koşulların farklılık göstermiş, yaşam alanları da buna paralel olarak dönüşmüştür. Bu dönüşümün, mekânsal yansımalarının ortaya çıkardığı sonuçlar, yapılarda oluşan değişimler ve ele alınacak yapıların günümüze kadar olan dönüşümlerinin, bulunduğu çevreye etkilerini tespit edebilmek çalışmanın amacıdır. Çalışmaya ilk olarak konunun temelini oluşturan CMC'nin adaya gelişi, bulunduğu bölgeye olan etkileri incelenerek başlanacaktır. Çalışmada kullanılacak kaynaklar için kütüphanelerin yanı sıra, internet üzerinden literatür taramalarına ve sözlü tarihe başvurulacaktır. Bunun yanı sıra, konunun son bölümü ile ilgili saha çalışması ile birlikte ele alınacak olan binalar üzerinden mekan analizi yapılacaktır. Daha sonra elde edilen kaynaklar 1şı̆̆ında bir çalışma ortaya konulacaktır.

\section{GEMIKONAĞI VE LEFKE (KARADAĞ) BÖLGELERİ'NDEKİ CMC TOPLU KONUTLARININ KARAKTERISTIK ÖZELLIKLERİ}

İnşası 1922 yılında başlayan konutların yapımı 1926 yılında Gemikonağı (Xero) Bölgesi'ndeki işçi evlerinin tamamlanmasının ardından, 1928'de Karadağ (Mavrovouni) Bölgesi'nde de ikinci bir işçi köyü kurulduğu görülmektedir. Bu toplu konutlar, biri Güney 
Kıbrıs'ta olmak üzere üç farklı bölgede inşa edilmiştir. Bahsi geçen bu konutların yapımımın 1970 y1lına kadar devam ettiği bilinmektedir. Konutlar, bekar işçi evleri, evli işçi evleri, ustabaşı (Foremen evleri) ve mühendis evleri olmak üzere toplam dört kategoride toplanmışlardır. Her kategori ise kendi içerisinde çeşitlilik göstermektedir (Çağanağa, 2014, pp. 52-224).

Gemikonağı Bölgesi’ndeki CMC toplu konutları, deniz kıyısının güneyinde Xero Deresi'nin batısında, CMC için kurulan tesislerin yakınında inşa edilmişlerdir. Günümüzde kurumuş olan bu dere, doğal bir sınır görevi görmekte, batısında konutlar ve doğusunda ise CMC tesisleri yer almaktaydı. Gemikonağı bölgesi düz olmasından dolayı tüm binalar kuzey-güney aksında inşa edilmiştir (Lavender, 1962) (şekil 1).

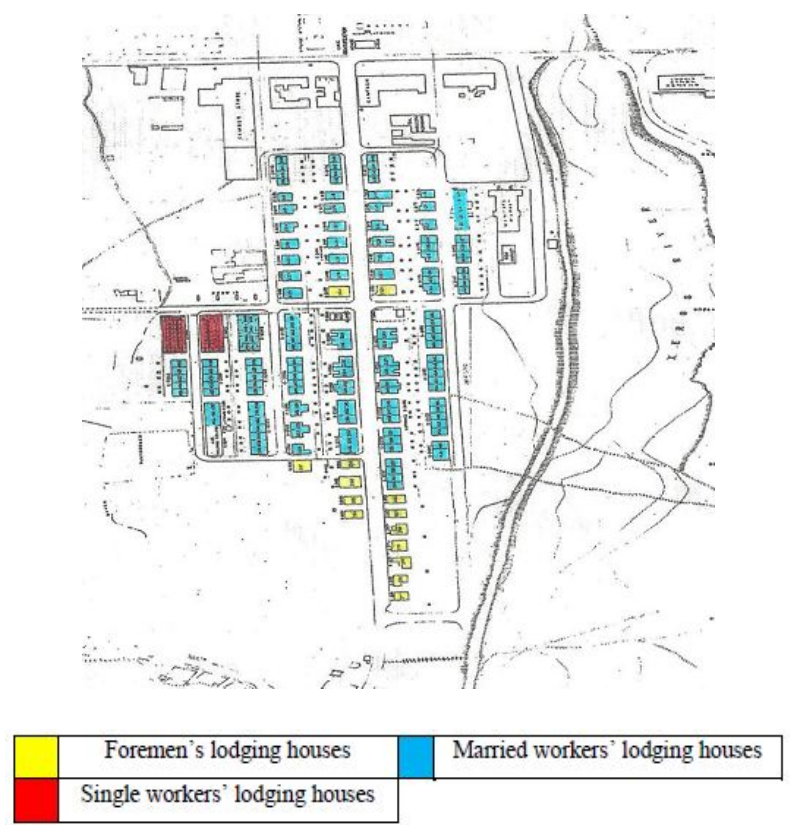

Şekil 1: Gemikonağı'ndaki CMC İşçi Toplu Konutlarına ait Harita

(Çağanağa, V., 2014)

\section{Bekar İşçi Evleri}

Bekar işçi evlerine hem Gemikonağı'nda hem de Karadağ Bölgesinde rastlanmaktadır. Evler, tek odalı, ortak terasları bulunan ve birbirine bitişik olarak konumlandırılmışlardır (şekil 2). Tuvaletler her iki-üç eve düşecek biçimde avluda konumlandırılmıştır. Avlularda ortak kullanılan tuvaletlerin yanı sıra çeşmeler de bulunmaktaydı. Bu çeşmelerden akan sular, üzeri açık ' $\mathrm{V}$ ' biçimindeki kanalizasyon kanallarıyla giderlere yönlendirilmektedir. Evlerin alanları 0.32 ile $0.34 \mathrm{~m}^{2}$ arası değişmektedir. Tek odanın içerisinde, bir yatma alanı ve mutfak bulunur. Mutfak eviyesi, evin içerisinde banyo olmadığından dolayı banyo amacı ile de kullanılmaktaydı. Zeminde döşeme bulunmamakta, dış duvarlar ise temele kadar beton sıva 
üzeri beyaz boyalı idi. Yapılardaki tek renk kırmızı boyalı ahşap pencere ve kapılar yapılan araştırmalarda dikkati çeker.

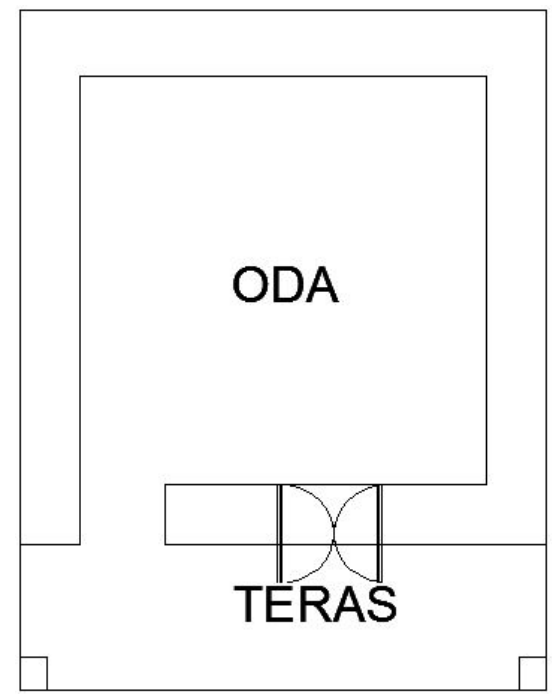

Şekil 2: Bekar İşçi Evleri orijinal plan (Gaye Anıl, 2015)

Ustabaşı Evli İşçi $\quad$ Bekar İşçi $\quad$ Mühendis

\begin{tabular}{|l|c|c|c|c|}
\hline Lefke(Karadağ) & 13 & 236 & 44 & 14 \\
\hline Gemikonağ1 & 14 & 138 & 40 & 17 \\
\hline
\end{tabular}

Tablo 1. 1938-1974 Lefke ve Gemikonağı bölgesindeki konut sayısı (Çağanağa, V., 2014)

\section{Evli İşci Evleri}

Evli işçi evleri, bekar işçi evlerine oranla daha büyük bir alana sahiptir. 0.40-0.50 m²'lik bu evlerin içerisinde, iki yatak odası, bir mutfak, salon ve teras bulunmaktaydı. Birbirinden bağımsız inşa edilmiş olan bu evlerin bekar işçi evlerinden farkı avlularında her eve ait tuvalet ve çeşmelerinin bulunmasıydı. Diğer evlerde kullanılan kanalizasyon sistemine bu evlerde de rastlanmaktadır. Sistemi olmayan evlerde ise septik havuz bulunmaktaydı (şekil 3). 


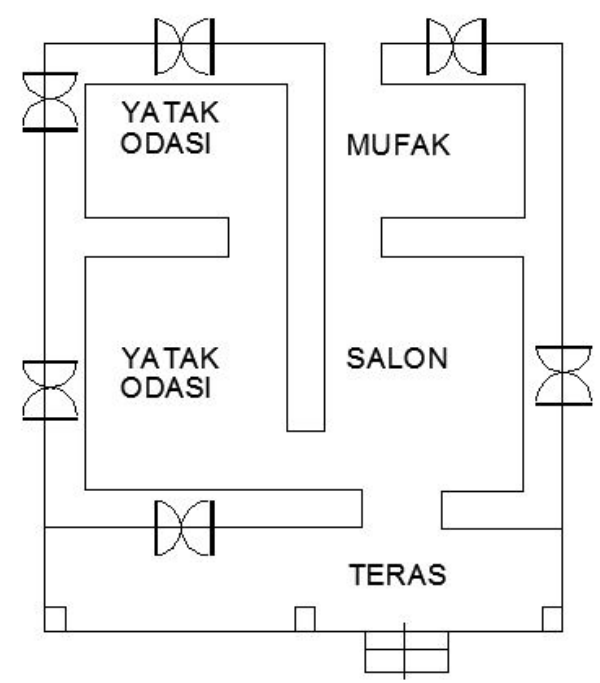

Şekil 3: Evli İşçi Evlerini Gösteren Orjinal Plan (Gaye Anıl, 2015)

Sokaktan evlerin giriş cephesine bakıldığında, giriş kapısının genellikle evlerin ortasında olduğu dikkati çekmektedir. Tüm kapı ve pencereler ahşaptan yapılmış, odalarda genellikle iki adet pencere kullanıldığı gözlemlenmektedir (Foto 1). Mutfak kapıları da, hem ustabaşı evlerinde hem de evli işçi evlerinde yataydan ikiye bölünmüş ahşaptan tasarlanmıştı. Kapının alt kısmı kapalı iken üst kısmı mutfağın havalandırılması amacı ile pencere gibi kullanılabilmekteydi (Foto 2).

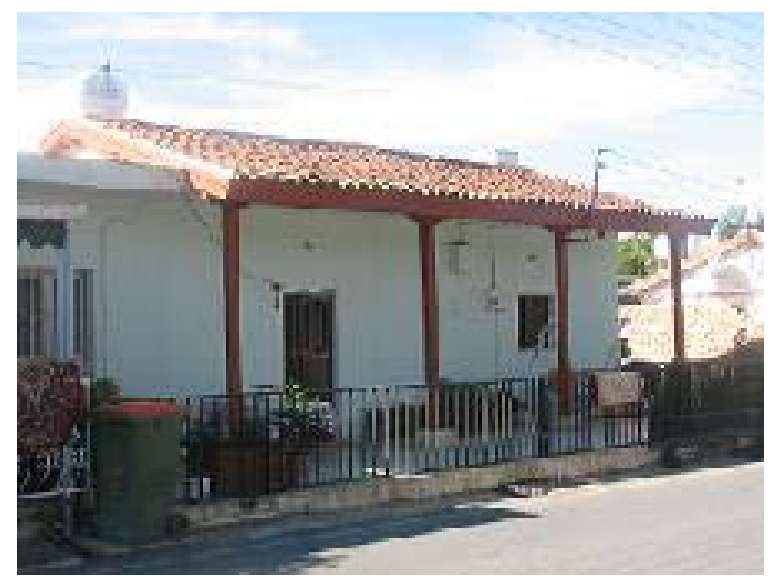

Foto 1: CMC Evli İşçi Evlerinin Tipik Ön Cephe Görünüşü (Gaye Anıl, 2015) 


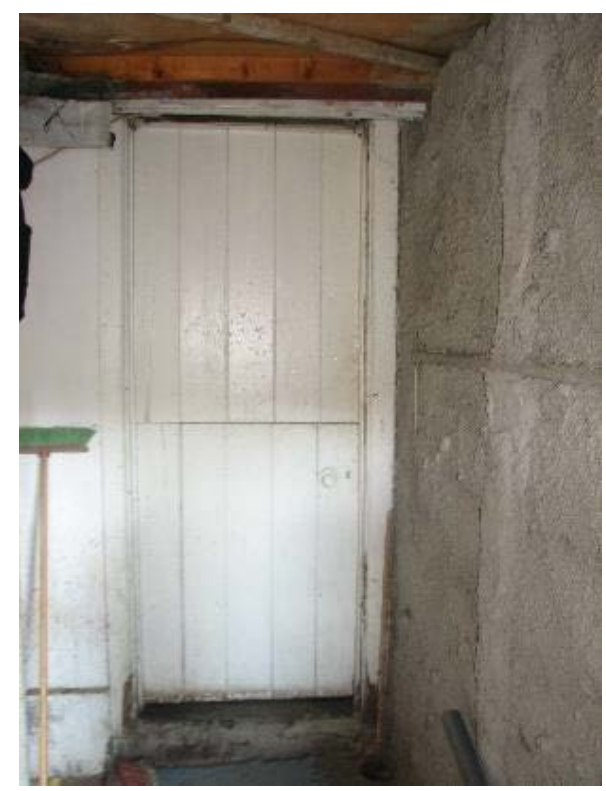

Foto 2: CMC Evli İşçi Evlerinin Mutfak Kapısı (Gaye Anı1, 2015)

\section{Ustabaşı Evleri}

İki bölgede de mevcut olan bu evler, sahada görev alan ustabaşları için tasarlanmışlardır. Taş temel üzerine, kırmızı ateş tuğla duvarlar ile kerpiç malzemenin birlikte kullanıldığı dikkate çekmektedir. Tavanlarda ise içeriden ahşap kaplı kiremit döşeli çatılar mevcuttur. Zeminde şap kullanıldığı yapılan araştırmalarda karşımıza çıkmaktadır. İnşaat için, iklimsel koşullara uygun ve en kolay elde edilen malzemeler kullanılmıştır. Cephelerinde veranda olan bu evlerin bir girişi, iki yatak odası ve mutfağı mevcuttur, ancak tuvalet bekar işçi evlerindeki gibi çeşme ile birlikte avluda yer almaktadır. Evlerin bahçeleri bekar işçi evlerine kıyasla daha büyüktür. Arka bahçelerinde tek odalı bir yapı daha bulunmaktadır. Bu odanın banyo amaçlı kullanıldığı bilinmektedir. V formundaki kanalizasyon kanalları bu evlerde de kullanılmaktaydı (şekil 4).

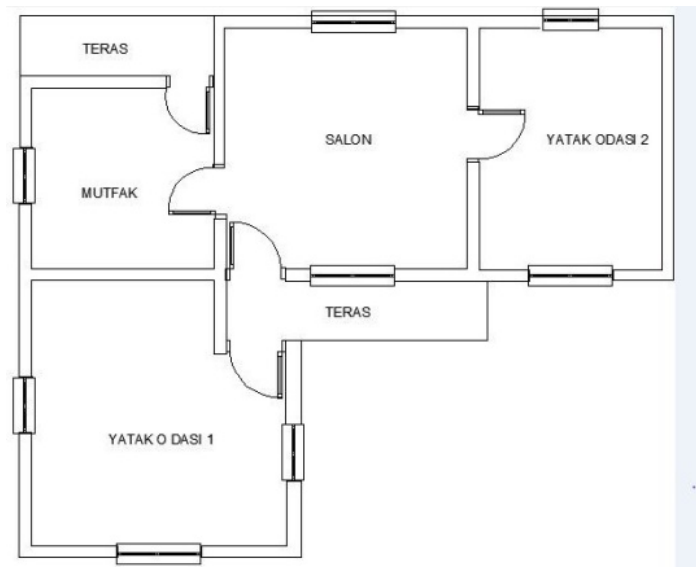

Şekil 4: ustabaşı işçi evlerini gösteren orjinal plan (Gaye Anıl, 2015) 
Evlerin içerisinde su şebekesi mevcut olmadığından, kullanıcılar tarafından evlerin arkasında kurulan çeşmelerden su temin edilmekteydi. Elektrik enerjisi ise, şirket tarafından kurulan merkezi bir üniteden sağlanmaktaydi.

\section{Mühendis Evleri}

Bugünün tabiri ile İngiliz Evleri, Gemikonağı'nda mühendislerin kullanımı için onyedi inşa edilmiştir. Villa tipi olan bu konutlar Laia adlı bir tepenin üzerinde, doğu yönüne doğru inşa edilmişlerdir. Konutlar, birbirinin önünü kapatmayacak biçimde manzaraya doğru tasarlanmışlardır (foto 3-4). Evler kuzey-güney yönünde düz bir sokak üzerine inşa edilmiş ve işçi evlerinden tamamen izole biçimde düzenlenmiştir. Dikdörtgen bir arsanın tam ortasına konumlandırılmış, alanları $0.804-0.1066 \mathrm{~m}^{2}$ arasında değişmektedir.

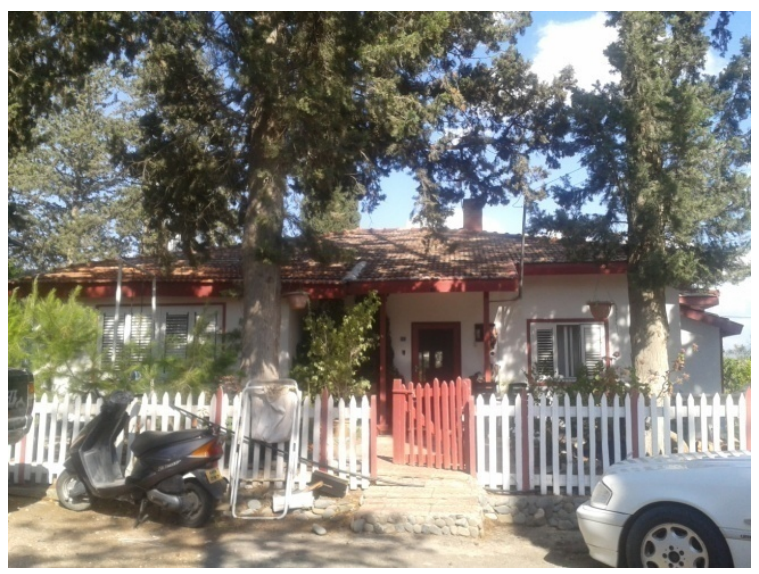

Foto 3: Mühendis Evlerine bir örnek (Gaye Anıl, 2015)

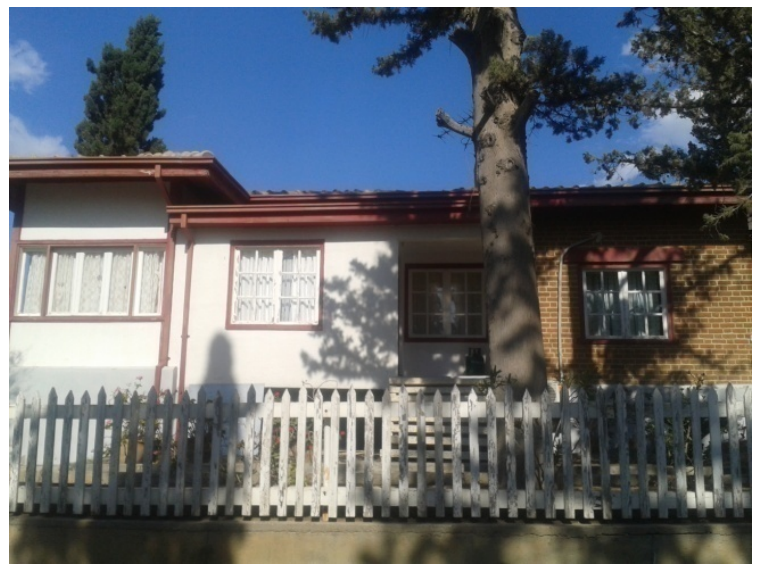

Foto 4: Mühendis Evlerine bir örnek (Gaye Anıl, 2015) 
Kendine ait bahçeleri beyaz ahşap çitlerle çevrili, evler ise kırmızı ateş tuğlasından oluşmaktadır. Kendine ait özel garajı ve iki üç odalı ve banyolu yardımcı evi bulunan mühendis evleri, tek katlı olup, üç yatak odası, şömine salonu, oturma odası, banyo tuvalet ve mutfaktan oluşmaktadır (şekil 5-7) (foto:5-10).

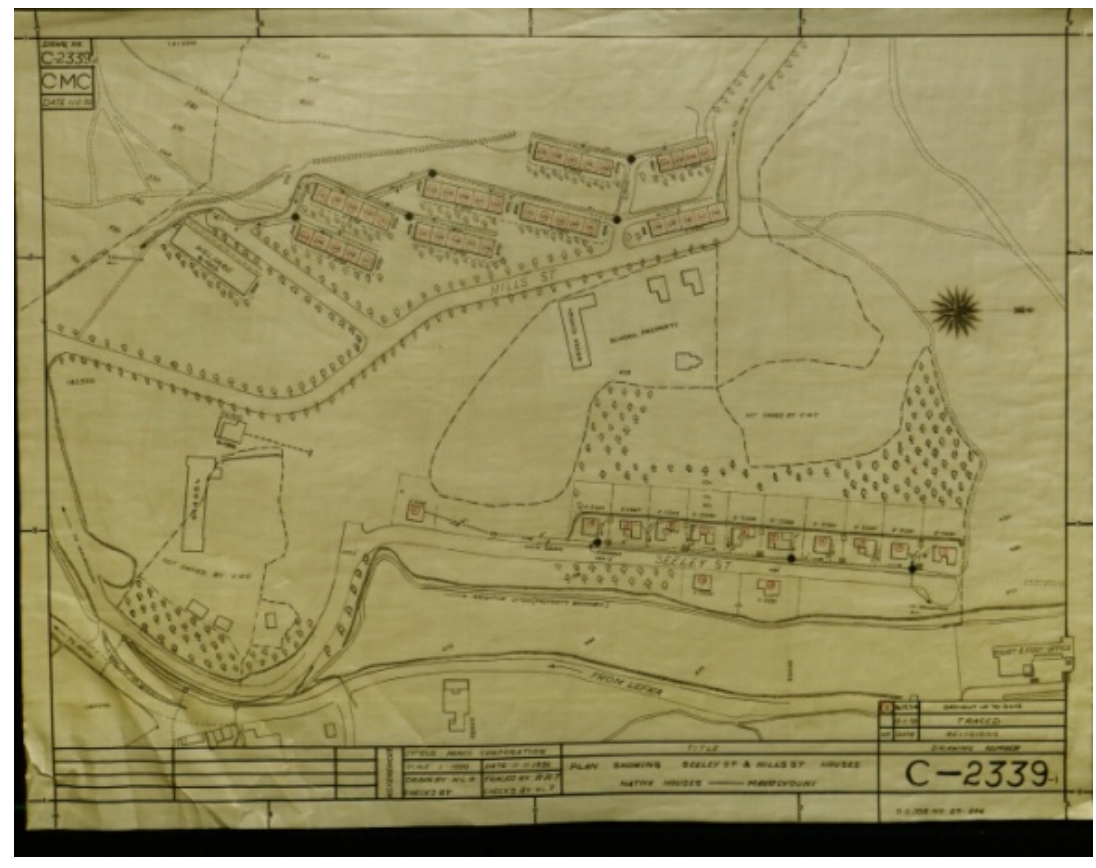

Şekil 5: Lefke Mühendis Evleri Yerleşkesi Planı

(Yakın Doğu Üniversitesi Kütüphanesi, CMC Arşiv Odası 2015)

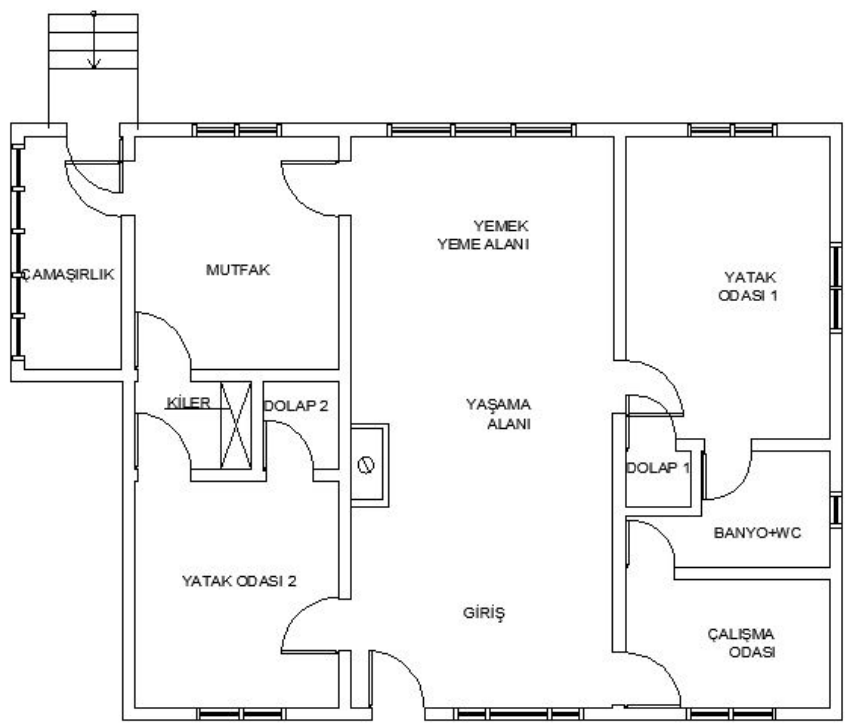

Şekil 6: Mühendis Evlerini Gösteren Orjinal Plan (Gaye Anıl, 2015) 


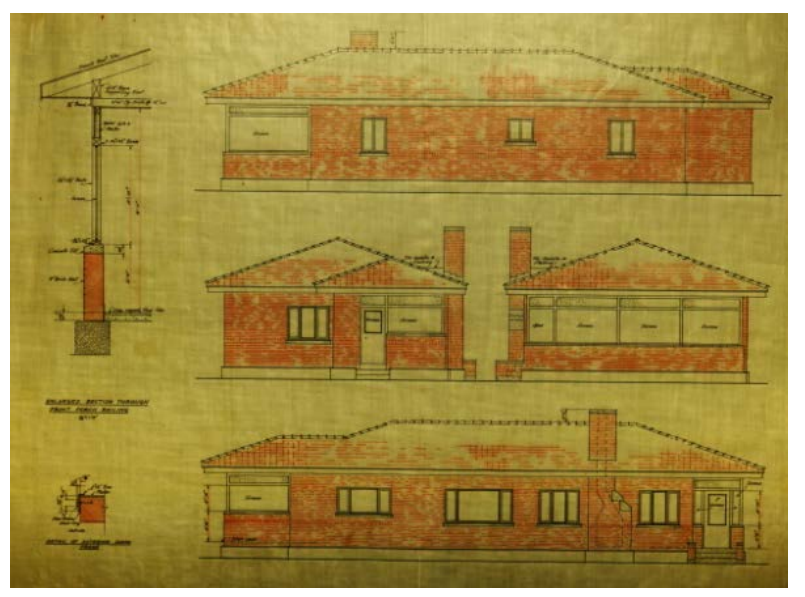

Şekil 7:Mühendis Evlerinin orijinal kesit ve görünüşleri,

(Yakın Doğu Üniversitesi Kütüphanesi, CMC Arşiv Odası 2015)

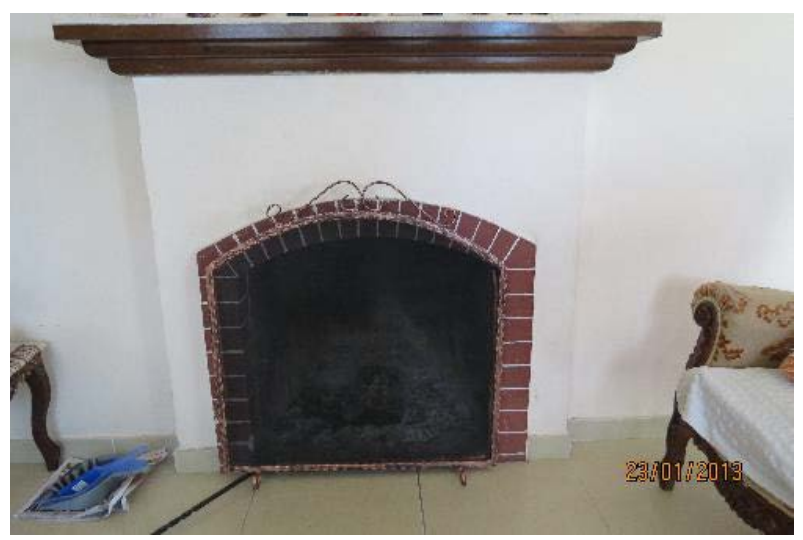

Foto 5: Mühendis Evlerindeki Mevcut Şömine (Gaye Anıl, 2015)

Şirket, konutlardaki tüm mobilyaların teminini sağlamaktaydı. Mühendis evlerindeki tüm mobilyalar, birbirinin aynı üretilmekteydi (Houssein, Y., 2013), Aktaran: Çağanağa, 2012). Şekil 8'deki mutfak çiziminde, konutlarda kullanılan dolaplar görülebilmektedir. Şekil 9'da ise 1952'de, mutfakta yapılmış olan değişikliğin çizimi yer almaktadır.

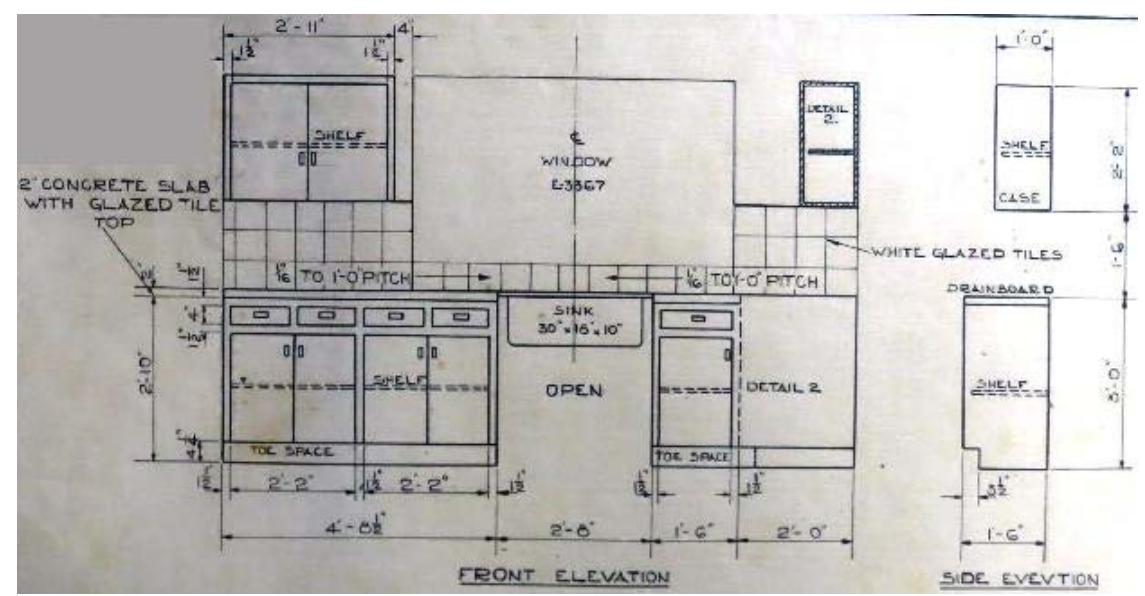

Şekil 8: Mühendis Evlerinin mutfakları İçin 1952 Tarihine Yapılmış Orjinal çizimler (Yakın Doğu Üniversitesi Kütüphanesi, CMC Arşiv Odası, 2015) 


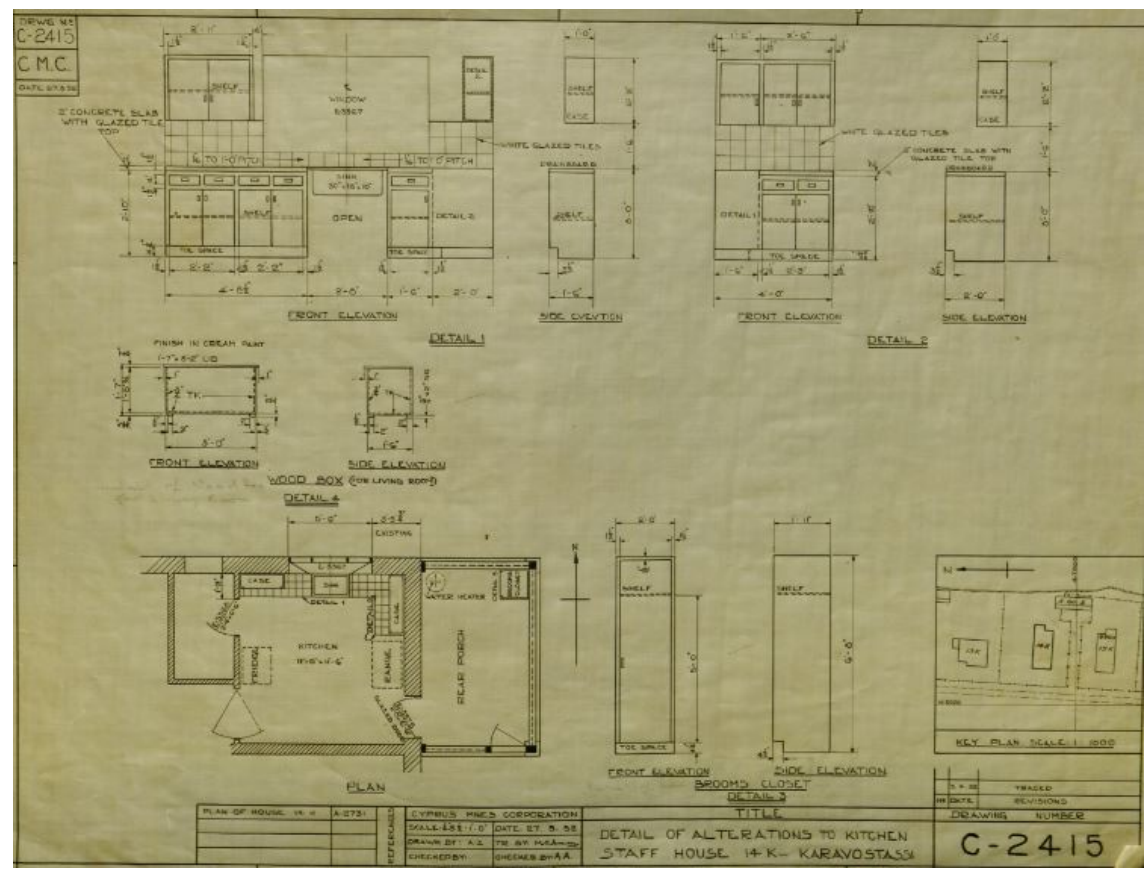

Şekil 9: Mühendis evlerindeki mutfakta 1952 yılında yapılmış olan değişikliklerin orjinal çizimi.

(Yakın Doğu Üniversitesi Kütüphanesi, CMC Arşiv Odası, 2015)

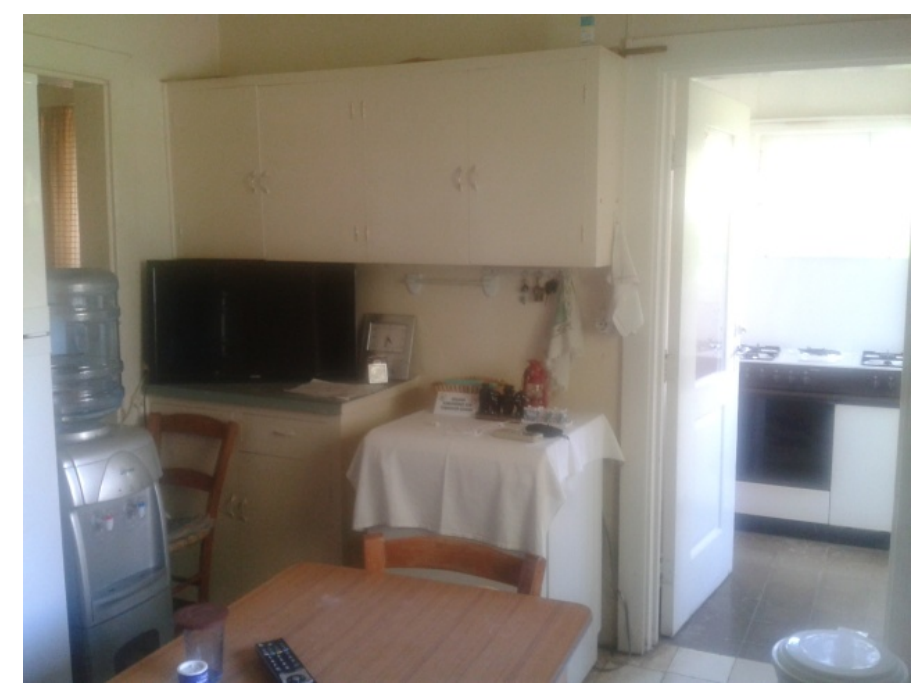

Foto 6: Mühendis Evlerinin Orjinal Mutfak Dolaplarına Bir Örnek

Refik Saydam Evi (Gaye Anıl, 2015)

Banyoda ise birer küvet, lavabo ve klozet mevcuttur. Klozetin üzerinde de duvara gömülü olarak düzenlenmiş bir ecza dolabı ile temizlik malzemeleri için iki kapaklı ahşap duvar dolabı mevcuttur. Foto 10 'da ecza dolabının günümüzde hala daha kullanıldığı görülmektedir. 


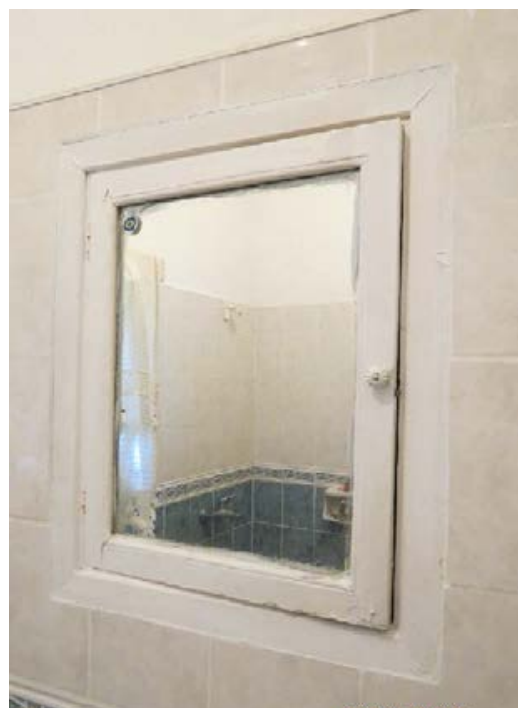

Foto 7: banyo odasındaki lavabonun üstünde bulunan ecza dolabı (Çağanağa, V., 2014)

Çeşmeler iç mekanda bulunmaktadır. Bahçeler, çim ve gölge amaçlı ekilen servi ağaçları ile kaplıydı. Eve arazi eğiminden dolayı basamaklarla girilmekteydi. Girişteki beyaz ahşap çerçeveli limonluk, evin karakteristik özelliklerinden biri olarak söylenebilir. Bu mekanlar ev sahipleri ve misafirleri tarafından sıklıkla oturma alanı olarak kullanılmaktaydı. Özellikle misafiri evin içerisine sokmadan ağırlamak ve soğuk kış günlerinde güneşin 1sısından yararlanmak için tercih edilen mekanlardı. Yapılan saçaklar, ev cephesini yağmurdan korumaktaydı. Çamaşır için sıcak su temini ise kurulan metal tank içerisindeki dizel yağ ile sağlanmaktaydı (foto 8). Septik havuz, kanalizasyon giderleri için her evin arka bahçesinde bulunmaktaydi.

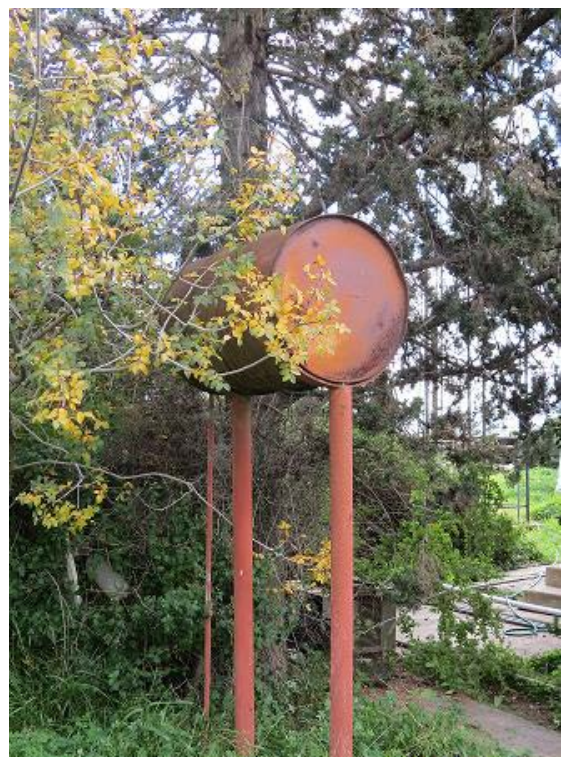

Foto 8: Mühendis Evinde Metal Fuel Tank1 (Gaye Anıl, 2015) 


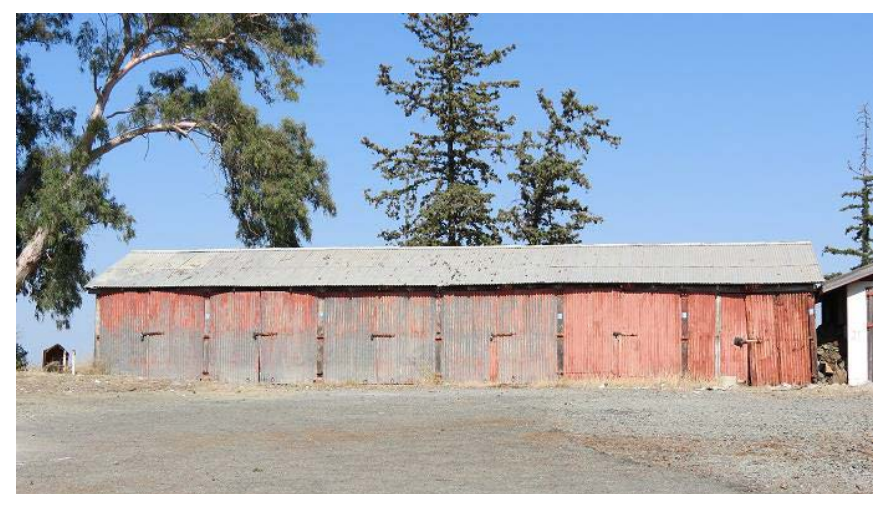

Foto 9: Her eve özel garajlar (Çağanağa, V., 2014)

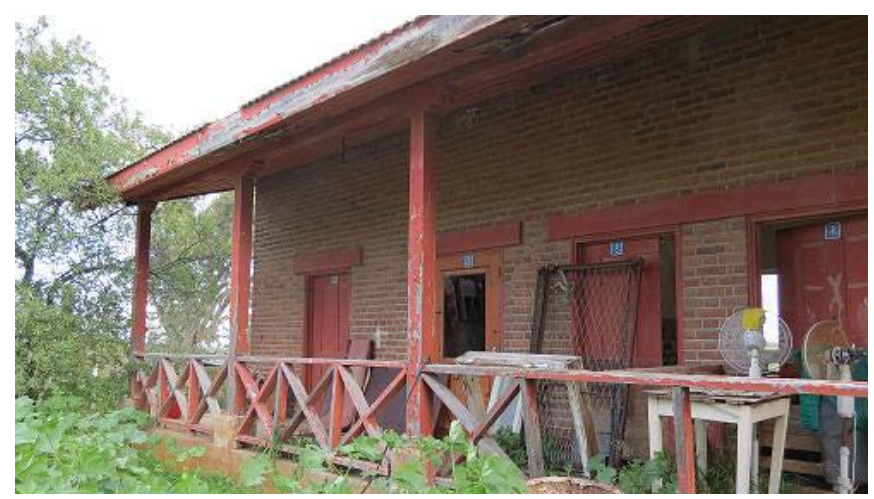

Foto 10: Mühendis evlerinin arkasında mevcut olan yardımcı Evlere bir Örnek; CMC tarafından 1922-1938, kuzey cephesi (Gaye Anıl, 2015)

\section{Üst kademe personelinin sosyal hayatları}

Üst kademedeki personelin aktif sosyal hayatları olduğu yapılan araştırmalarda karşımıza çıkmaktadır (Anıl C. 2015, sözlü kaynak). Evlerde ya da Skuriotissa Bölgesi'ndeki şirkete ait kulüpte hafta sonu partileri ya da toplantıları ile bir araya gelmekteydiler. Konutların civarındaki golf sahası, tenis kortları ve sinema salonları, çalışanların kamusal mekanlarda zaman geçirdiklerinin bir göstergesidir (Houssein, 2013). Sinema ve kulüp gibi diğer mekanları ise Karadağ ve Gemikonağı'nda yaşayanlar daha çok kullanabilmekteydi. Ayrıca, ürünlerin çoğunun Amerika ve İngiltere'den tedarik edildiği bilinen, bakkal, manav, kasap gibi ortak kullanım alanlarının yanısıra mühendislere ait özel alışveriş mekanları yer aldığı yapılan araştırmalarda karşımıza çıkmaktadır.

Bahçe kullanımı, adanın iklimi açısından önemli bir yere sahipti. Bahçeler, her zaman temiz, düzenli ve bakımlı tutulmaktaydı. Özellikle arka bahçelerde özel toplantılar için biraraya gelinmekte olduğu yapılan araştırmalarda dikkati çekmektedir (Anıl C., 2015, sözlü kaynak). 


\section{CMC EVLERININ TRANSFORMASYONU}

Geçmişte inşa edilip günümüze kadar gelen konutlara baktığımız zaman birçoğunu eski fonksiyonları kaybolmuş ve yeniden işlevlendirilerek yenilenmeye çalışılmış olduğunu görmekteyiz. Değişen ihtiyaçlara göre bu konutların ve onlara yapılan eklerin günümüz ihtiyaçlarına göre yeniden işlevlendirilmesi toplumun sosyal ve kültürel anlamda değişime uğramasından dolayı karşılaşılan bir durum olduğu bilinen bir gerçektir.

Daha öncede değinildiği üzere, şirkete ait işçileri, ustabaşları ve idari personel için düzenlenen ve Gemikonağı'nda yer alan CMC evleri, 1zgara sisteminde kuzey ve güney istikametine doğru düzenlenip, tasarlanmıştır. Böylece o bölgede var olan Xero Deresi batıdaki evlerle doğudaki şirkete ait tesislerine doğal bir sınır oluşturmuştur.

CMC Evleri ve bu evlerin çevresinde oluşan ona bağlı farklı fonksiyonlardaki diğer yapılar da sosyal ve kültürel değişimden etkilenerek zamanla dönüşüme uğramışlardır. Bunlara sırayla bakacak olursak;

Gemikonağı'nda işçi evleri ile maden tesisleri arasında endüstriyel alan kurulmuştur. 1974'e kadar balık pazarı olarak faaliyet gösteren günümüzde araç kaporta ve boyahane olarak kullanılmaktadır. O dönemin kapalı çarşısı ise bugün demir atölyesi olarak işlevini sürdürmektedir. Önceleri kantin olarak faaliyet gösteren bina ise şuan banka olarak işlevlendirilmiştir. Sahil ile anayol arasında bulunan ve CMC'nin kimliğini yansıtan ana bina ise askere ait bir yapı olarak işlevini sürdürmektedir. O dönem CMC'nin aylıkçı personel derneği olarak kulanılan bina şimdilerde Mücahitler Derneği olarak kullanılmaktadır. Eski polis binası ise 1974 sonrasından günümüze kadar kahvehane olarak değerlendirilmiştir.

Bunun yanısıra, sahil boyunca doğu-batı yönünde olan Gemikonağı-Yedidalga yolu üzerinde polis istasyonu, bazı dükkanlar, CMC aylıkçı Memur Derneği'nin binası ve CMC Kimlik binası yer almaktaydı. Sokaklar, evlere, eski balık dükkanına ve kapalı çarşıya ulaşım için kullanılmaktaydı. Yerleşmiş bölgelerde kıyıya yalnızca ana sokaktan gidilebilmekteydi. Burada doğu-batı istikametinde bir sokak daha vardı ancak bu sokak üzerinde şirket tarafından inşa edilen hiçbir bina mevcut değildi. Ancak bu durum şirketin 1974 yılında adadan ayrılması ile sonra değişmiş, hatta yapıların ve düzenin karakteristik özelliklerinin de dönüşüme uğramış olduğu gözlemlenmektedir.

Günümüzde bu evlerin dört tanesi sivil halk tarafindan, geriye kalan on üç ev ise asker tarafından kullanılmaktadır. Analizi yapılan evler de sivil halk tarafindan kullanılan bu dört evden oluşmaktadır. 


\section{Bekar İşç Evi}

Bekar işçi evleri için İlkay-Münevver Gümüşhan isimli çiftin konutu örnek olarak seçilip analizi yapılmıştır. Bu tip evler tek odalı olarak tasarlanmış ancak, 1974'ten sonra ihtiyaç doğrultusunda değişime uğramıştır. Analizi yapılmış olan bu konutta, beş tane ev birleştirilerek tek bir konut oluşturulmuştur. Şekil 10`da, Gümüşhan ailesinin konut planlaması ve odalara verdikleri fonksiyonları şematik olarak görülmektedir. Foto 11 ve foto 12'te değişime uğramış konutun yaşama mekanı, girişi ve mutfağa geçiş bölümü görülebilmektedir.

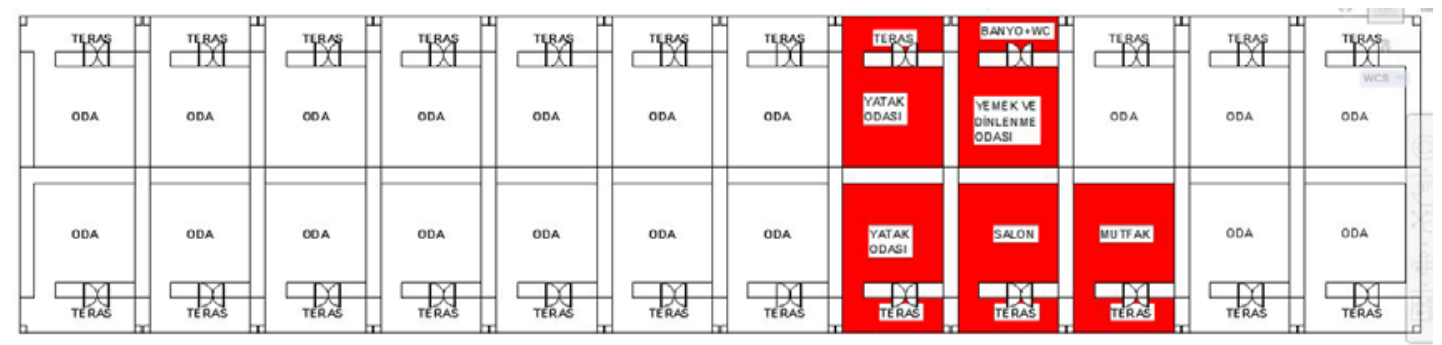

Şekil 10: Karadağ Bölgesi’ndeki Bekar Evleri, İlkay-Münevver 2015: Gümüşhan konut planı (Gaye An11, 2015)

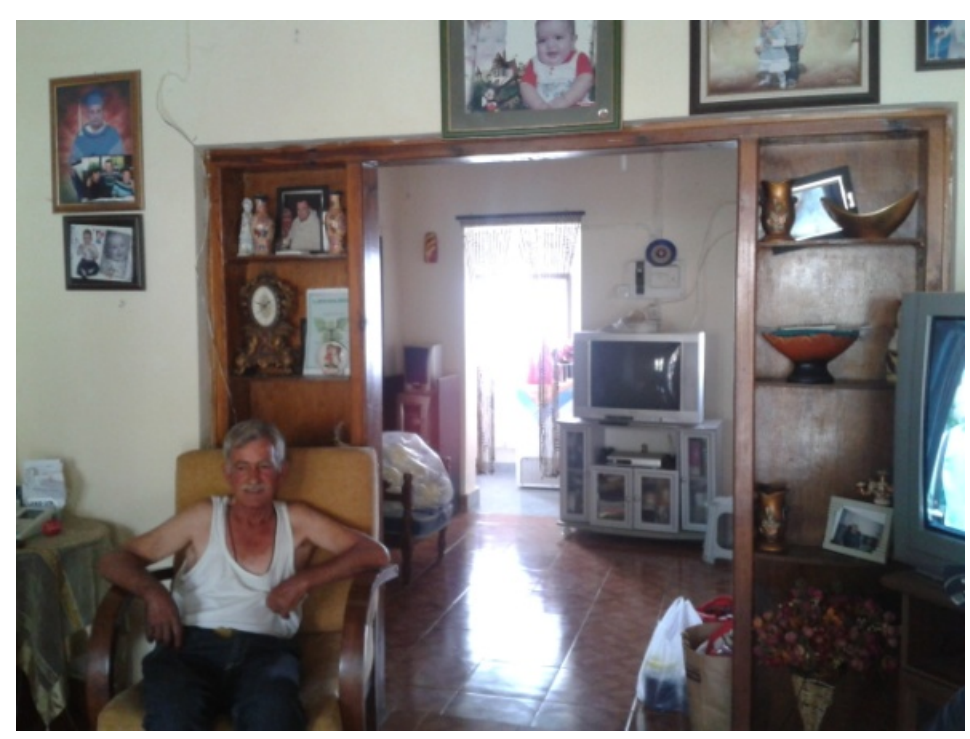

Foto 11: Karadağ Bölgesi'ndeki Bekar İşçi Evlerinde, Gümüşhan ailesinin konutunun yaşama alanından bir görünüm (Gaye Anıl, 2015) 


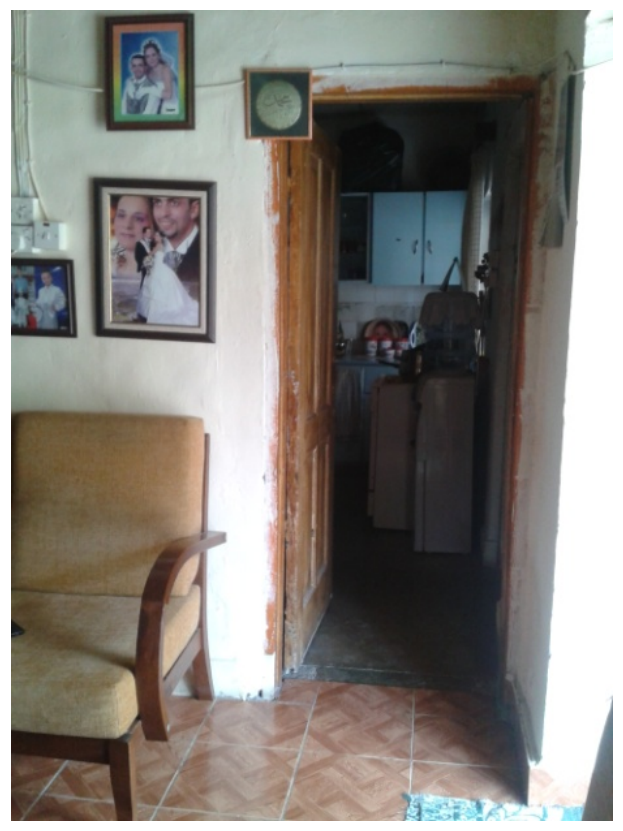

Foto 12: Karadağ Bölgesi’ndeki Bekar İşçi Evlerinde, Gümüşhan ailesinin yaşama alanından mutfak görünümü (Gaye Anıl, 2015)

\section{Evli İşçi Evleri}

Burada analizi yapılan konut, İbrahim - Nevgül Sağkanat çiftine aittir. Tipik evli işçi evlerinin iki ayrı hanesinin bir araya getirilmesi ile tek bir konut haline dönüştürülmüştür. $\mathrm{Bu}$ tip konut tiplerinde her konutta özel banyo+wc bulunmadığından dolayı, konuttaki mevcut mutfaklardan bir tanesi banyo+wc olarak değiştirilirken, binaya ek olarak mutfak ilave edilmiştir. Şekil 11'de evli işçi evlerinin orijinal planı görülmektedir. İşaretli bölge, Şekil 12'de, Sağkanat çiftinin konutu almalarından sonra, ihtiyaçları doğrultusunda nasıl değiştiğini göstermektedir. Foto 13 'de ilave edilip büyütülen mutfak bölümünün iç mekanı görülmektedir. Planda görülen ikinci mutfak, banyo ve WC ye çevrilirken, iki salon tek bir salon olarak düzenlenerek tek bir konut haline getirilmiştir.

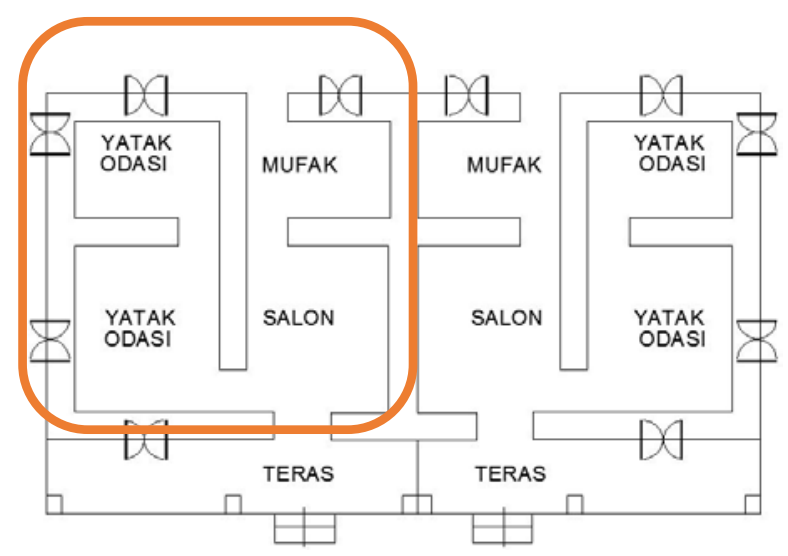


Şekil 11: Gemikonă̆ Bölgesi’ndeki evli işçi orijinal konut planına bir örnek (İbrahimNevgül Sağkanat evi)

(Gaye An1l, 2015)

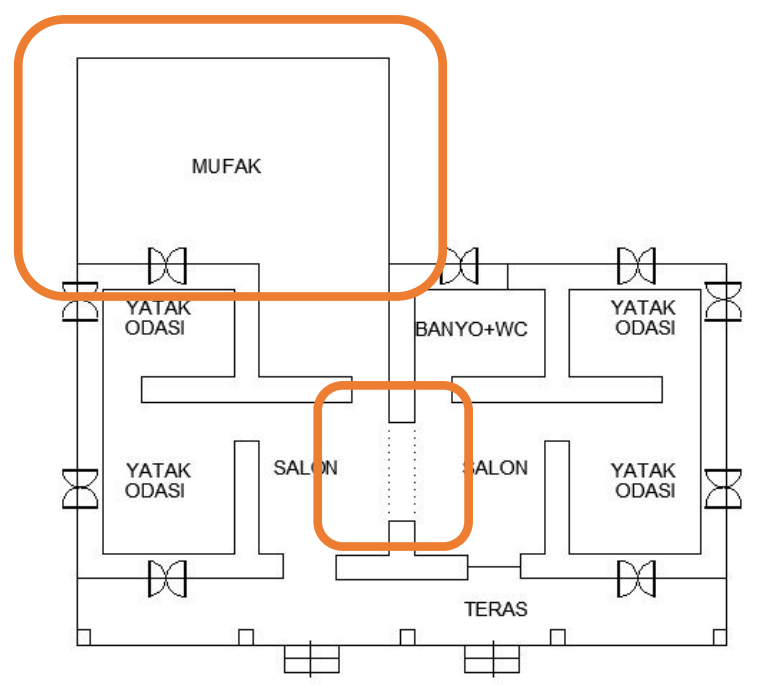

Şekil 12: Gemikonağı Bölgesi’ndeki Evli İşçi Konut planına bir örnek (İbrahim-Nevgül Sağkanat evi)

Değişmiş Plan (Gaye Anıl, 2015)

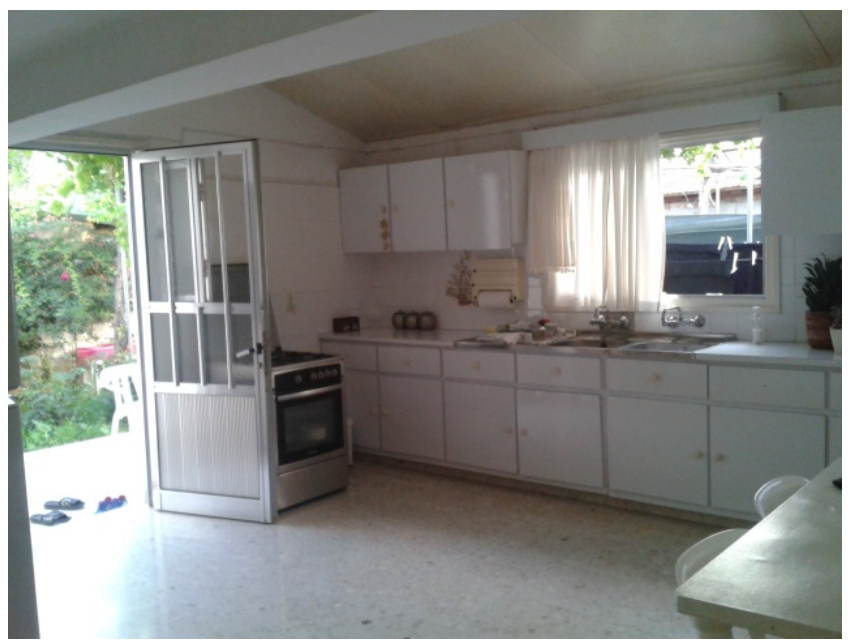

Foto 13: Sağkanat çiftinin, daha sonradan eklemiş olduğu mutfak kısmından bir görünüm (Gaye An11, 2015) 


\section{Ustabaşı Evleri}

Ustabaşı evlerine örnek olarak Nalan Akdağ isimli kişinin konutu ele alınmıştır (şekil 13). Orijinal planında mutfakla bağlantılı olan teras, günümüzde banyo ve wc olarak değiştirilirken salon ile ilişkili olan teras ise, yemek yeme bölümü olarak düzenlenmiştir. Salonda mevcut olan pencere ise ihtiyaç doğrultusunda giriş kapısına çevrilmiştir (şekil 14) (Foto 14-17).

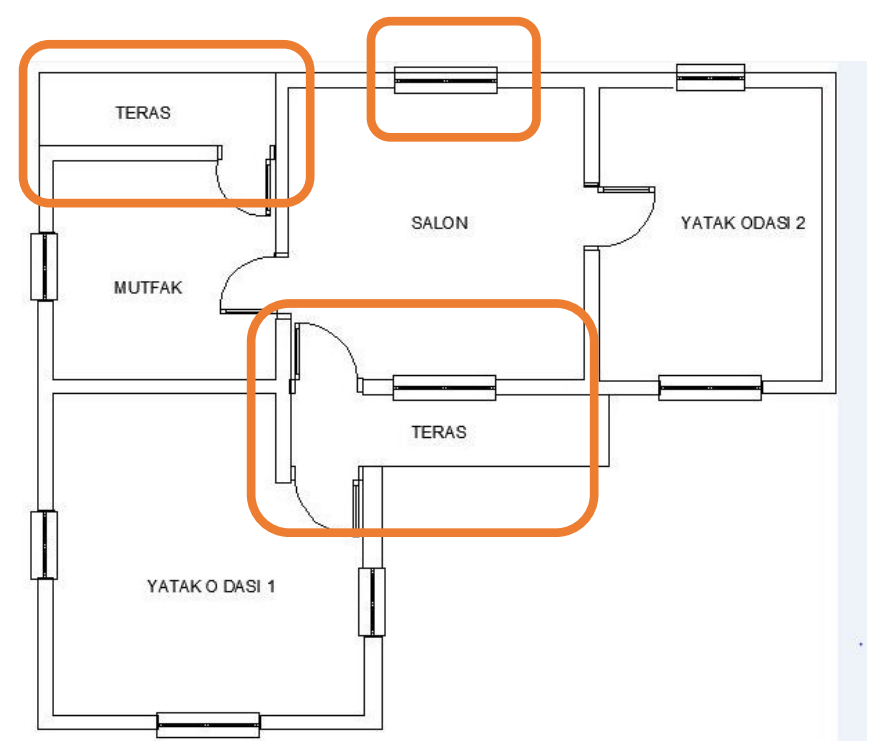

Şekil 13: Gemikonağı Bölgesindeki Ustabaşı Evlerinin orijinal planı, Nalan Akdağ konutunun değişim öncesi (Gaye Anıl, 2015)

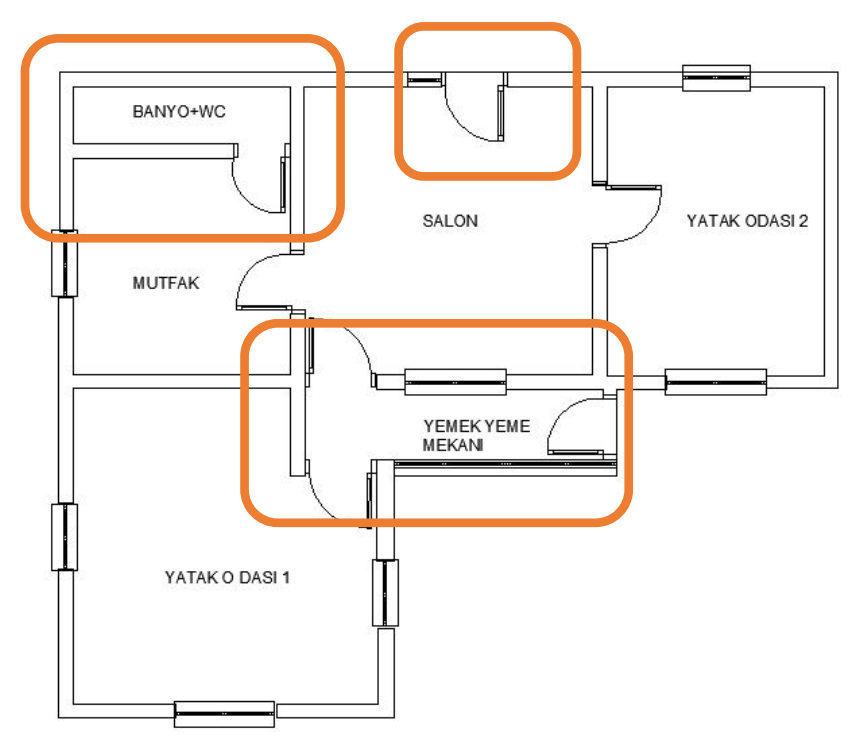

Şekil 14: Gemikonağı Bölgesindeki Nalan Akdağ konutunun ihtiyaç doğrultusunda dönüşüm sonrası (Gaye Anı1, 2015) 


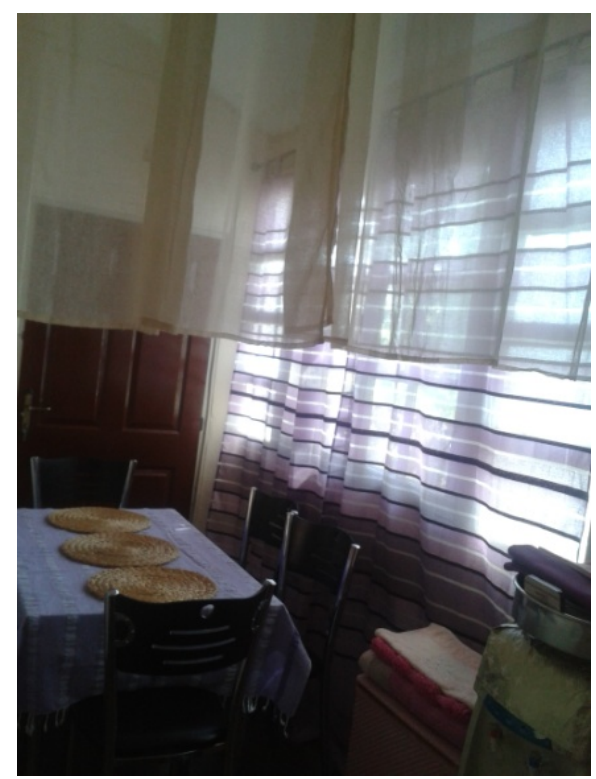

Foto 14: Nalan Akdağ'a ait konutun yemek yeme bölümünden bir görünüş (Gaye Anıl, 2015)

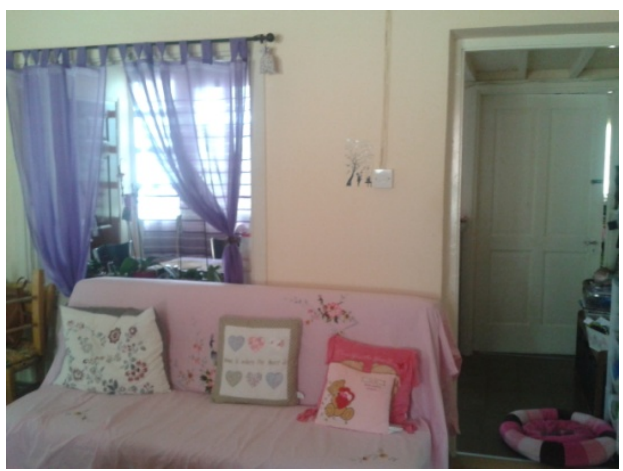

Foto 15: Konutun giriş kapıs1, yaşama alanı ve yemek bölümünden bir görünüm (Gaye Anı1, 2015)

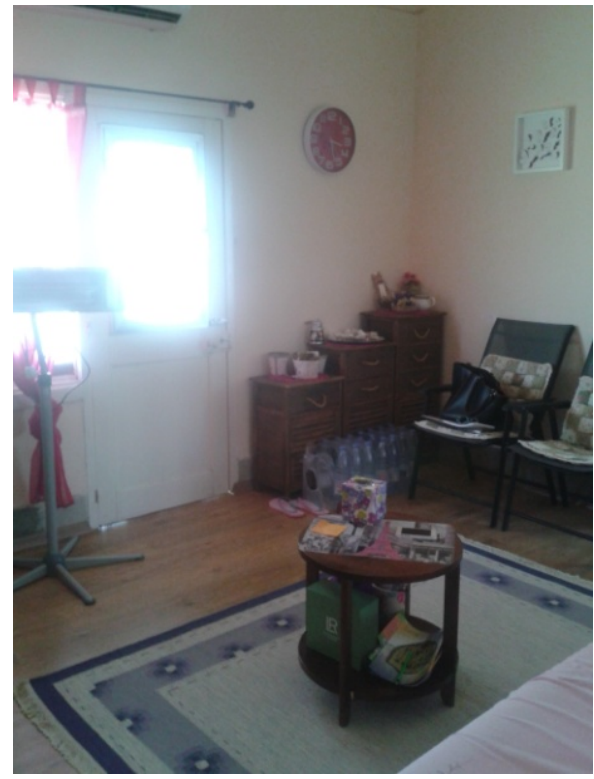

Foto 16: Nalan Akdağ’a ait konutun iç mekanından bir görünüş (Gaye Anı1, 2015) 


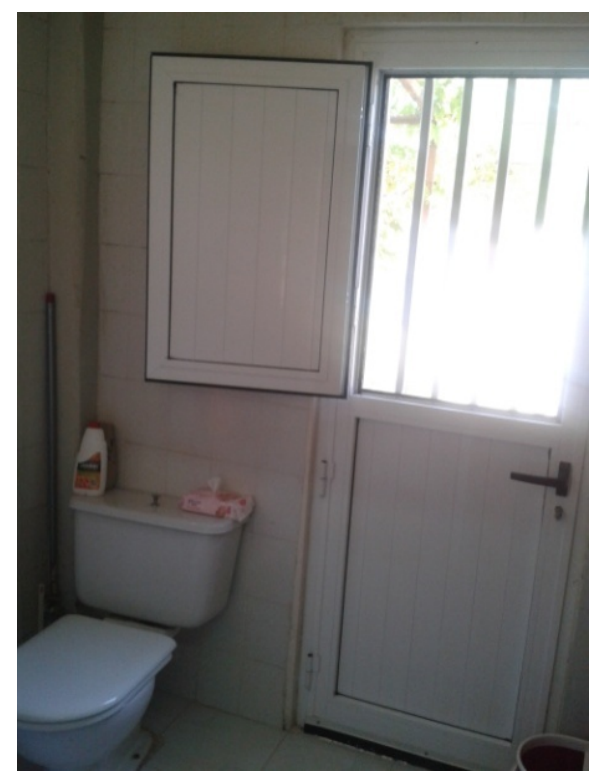

Foto 17: Konutun sonradan ilave edilen banyo ve WC sinden bir görünüş (Gaye Anıl, 2015)

\section{Mühendis Evleri}

Mühendis Evleri için Refik-Ümran Saydam isimli çiftin konutu ele alınarak inceleme yapılmıştır. Yukarıda da belirtildiği üzere, evlerin büyüklüğü ve biçimlenişi açısından, yapılarda herhangi bir form değişikliğine gidilmeden, neredeyse orijinaline sadık kalınarak kullanıldığı gözlemlenmiştir(Şekil 15). Foto 18 ve 19'da konutun giriş cephesi ve bahçeye açılan arka cephesi görülmektedir. Buradan da anlaşıldığı üzere konutta kullanılan malzemeler hala daha günümüzde de kullanılmakta olduğu dikkati çekmektedir. Konutun içerisindeki kullanım alanlarının da halen orijinal fonksiyonlarda var oldukları gözlemlenir (Foto 20-22).

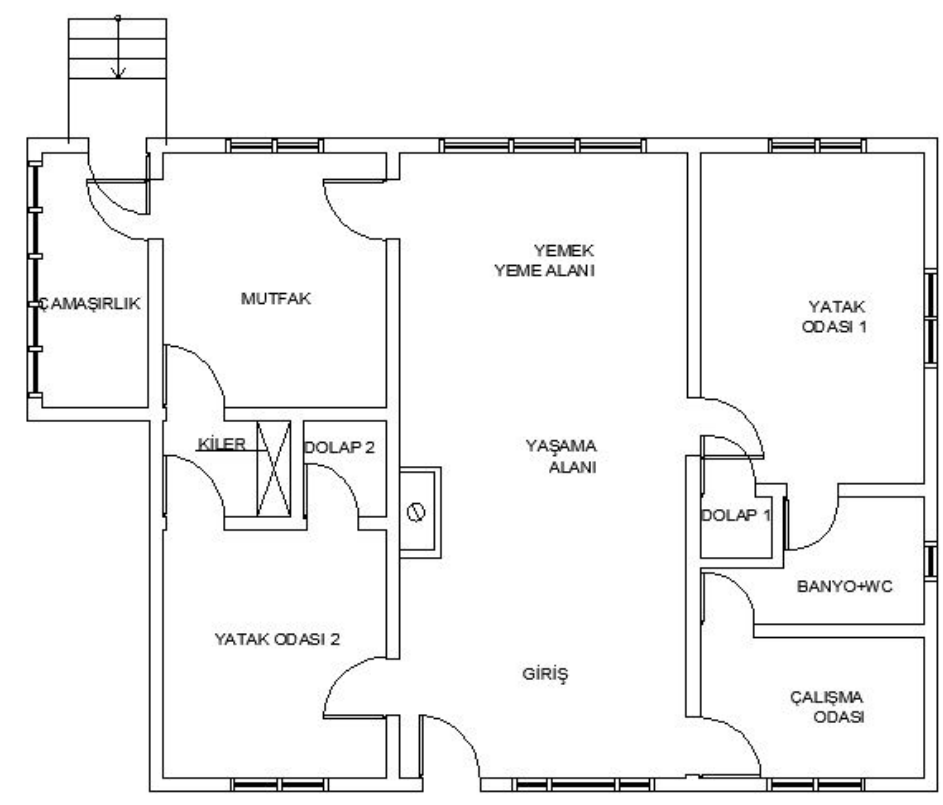

Şekil 15: Saydam ailesine ait konutun orijinal planı (Gaye Anı1, 2015) 


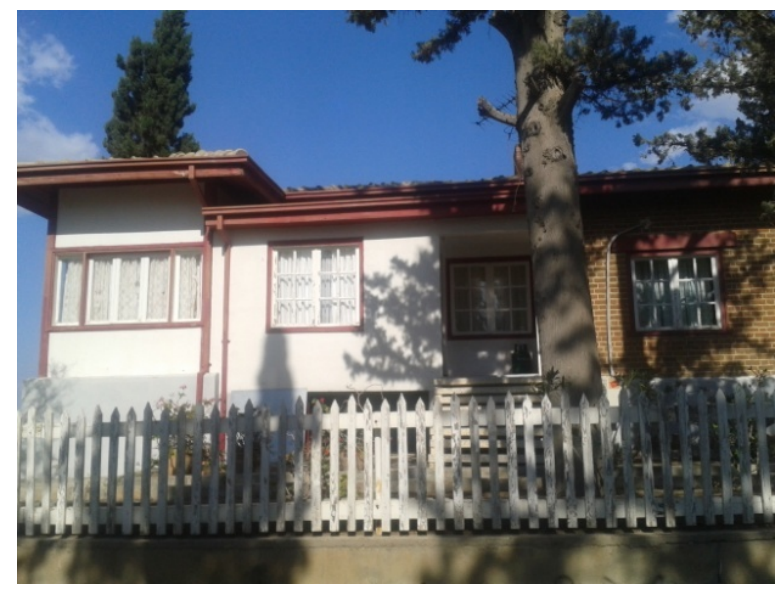

Foto 18: Saydam ailesine ait konutun ön cephesi (Gaye An1l, 2015)

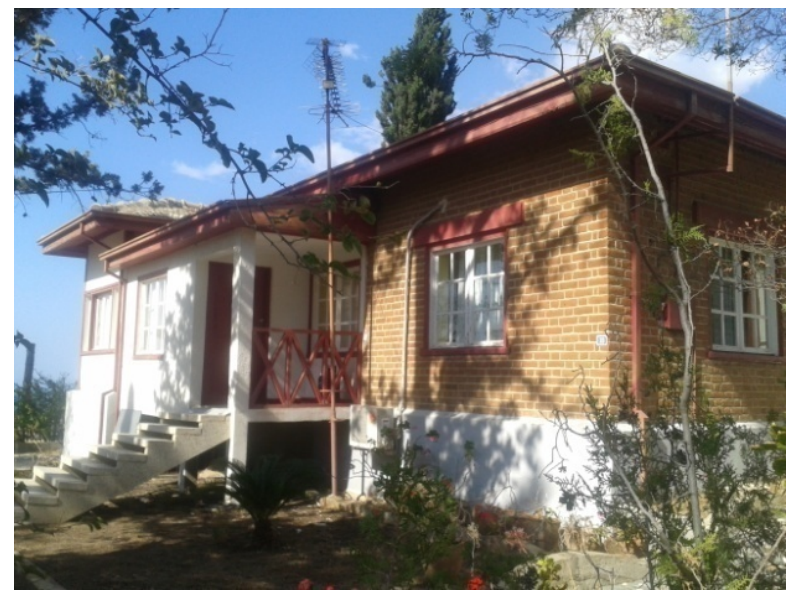

Foto 19: Saydam ailesi konutun arka cephesi ve kısmi bahçe görünümü (Gaye Anıl, 2015)

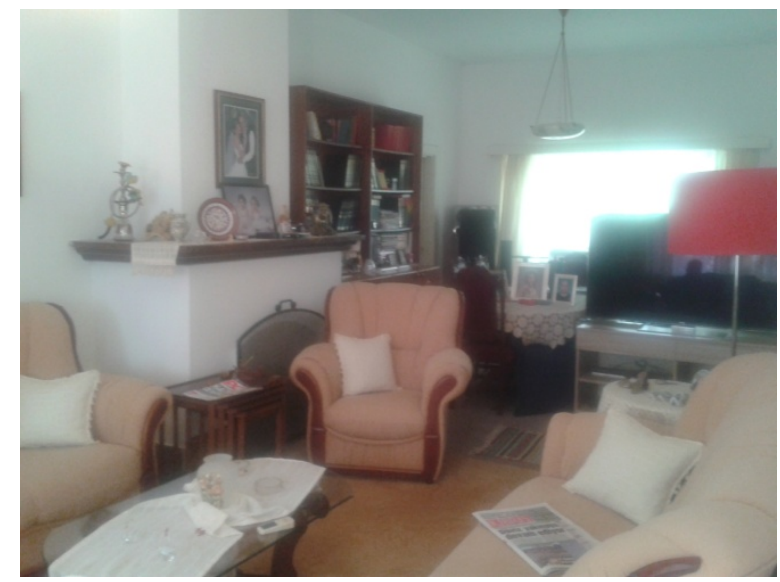

Foto 20: Saydam ailesi konutunun yaşama mekanından bir görünüm (Gaye Anıl, 2015) 


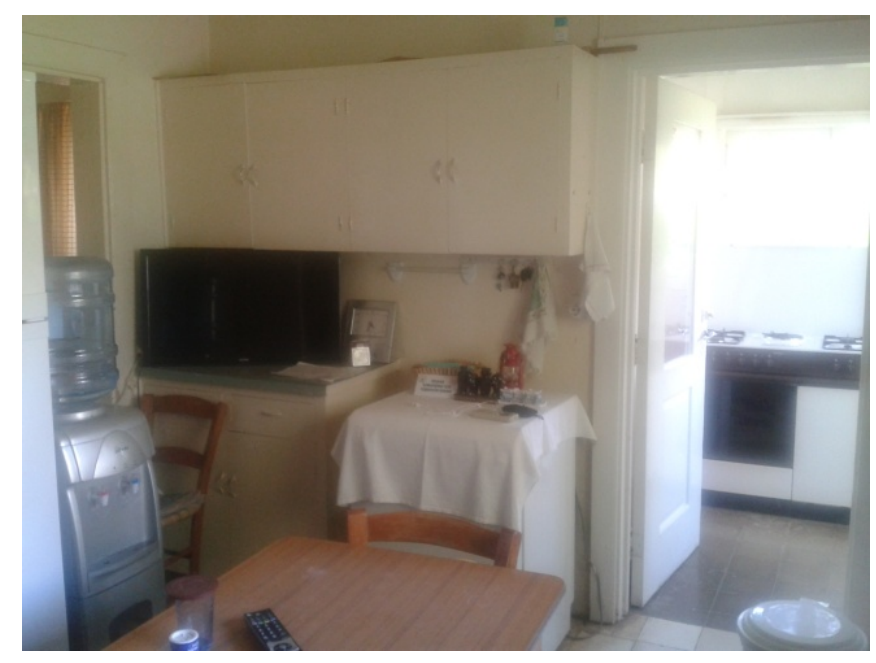

Foto 21: Konutun mutfak bölümünden bir görünüm (Gaye Anıl, 2015)

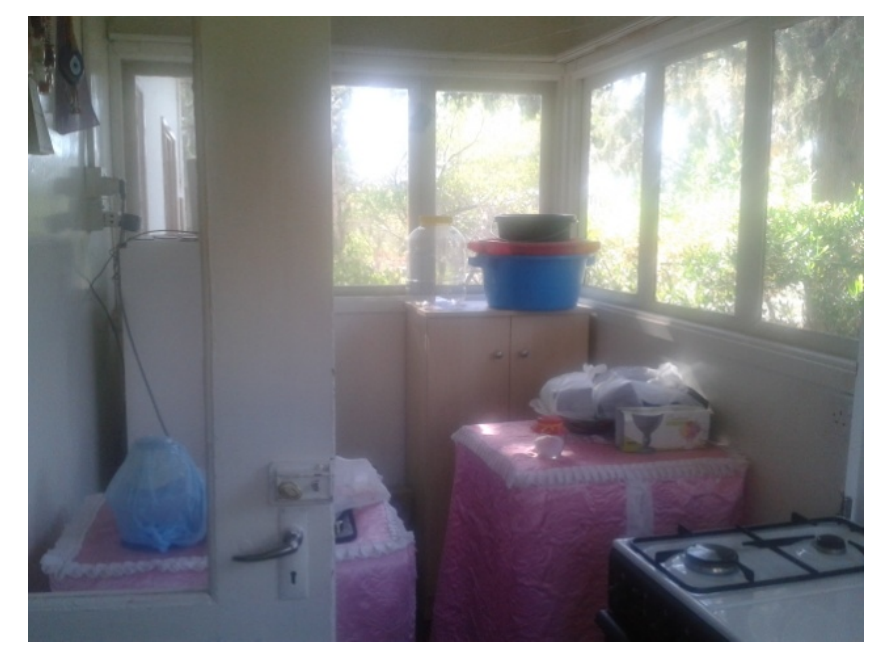

Foto 22: Konutun çamaşırlık bölümünden bir görünüm (Gaye Anı1, 2015)

\section{SONUÇ}

Dünya genelinde konutlar tasarlanırken kullanıcı ihtiyacı göz önünde bulundurularak uygulanmaktadır. Tarihsel süreçte bu uygulamalar değişip dönüşebilmektedir. Kullanıcıların değişmesi, buna bağlı olarak ihtiyaçlarının, ekonomik koşullarının, buna dayalı sosyal ve kültürel farklılıkların değişim göstermesiyle konutlarda dönüşüm oluşmasına olanak sağlamaktadır.

Yapılan çalışma, Lefke Bölgesi'ndeki CMC maden şirketinin 1920 yıllarında adaya gelmesi ve işçilerin kullanımına yönelik inşa edilmiş işçi konutlarını kapsamaktadır. Bölge genelinde mevcut konutların yetersiz olmasından dolayı şirketin, Karadağ, Gemikonağı ve Güney Kıbrıs'ta (Skouriotissa) bölgelerinde işçilere yönelik konutların tasarlandığı görülmüştür. Bu 
durum Lefke nüfusunu kayda değer şekilde çoğaltmıştır. Söz konusu konutların o dönemde toplam dört kategori çerçevesinde uygulandığ 1 ve tarihsel süreçte değişime uğradıkları gözlemlenmiştir.

1974 sonrası CMC konutlarının çoğunun dar gelirli kişiler tarafından kullanıldığı görülmektedir. Günümüzde hala daha işlevini sürdürmekte olan bu konutlarda, zorunlu kalınmadıkça değişiklik yapılmadığı bilinmektedir. Buna karşın konutlarda yapılan değişiklikler ise orijinal yapı malzemesine, renk ve doku niteliklerine sadık kalınmadan yapıldı̆̆ gözlemlenmiştir.

CMC Maden Şirketinin 1974'te adayı terk etmesinden sonra evlerin idaresi önce Devlet Emlak Malzeme Bakanlığı'na, daha sonra da Lefke Belediyesi'ne geçmiştir. CMC’nin faaliyette bulunduğu 1913 - 1974 yılları arasında Lefke ile yakın çevresinin ekonomisine önemli katkı sağlamış, sosyal yaşamı canlandırmış, nüfusta ciddi boyutta bir artış gözlemlenmiştir. Hatta günümüzdeki Lefke nüfusunun, o dönemlerdeki nüfus kadar olduğu bilinmektedir. Ancak, öte yandan, 1974 yılında CMC'nin kapatılması sonucunda geride kalan yaklaşık 10 milyon tonluk maden atığının çevreye verdiği ve halen bugün vermeye devam ettiği zararın oldukça ciddi boyutlarda olduğu bilinmektedir. Bölgede, ekolojik yapının bozulmasının yanısıra suyu da içilemez bir duruma gelmiştir. Kirlilik deniz ve kara canlılarını etkilemiş, maden tozunu sayesinde tüm ağaçlar zarar görmüştür. Gemikonağı içerisinde bulunan ve halen günümüzde hurda olarak duran demir yığınları, maden atıkları, doğaya ve çevreye verdiği zararın yanısıra, doğal güzelliği bozarak görüntü kirliliğine yol açmaktadır. Zamanla, CMC'ye ait yapıların el değiştirmesi ile yapılarda birtakım form değişiklikleri oluşmasına neden olmuştur. Kullanıcı ihtiyaçlarına yönelik bu dönüşümlerin, yapıların büyüklüklerine göre değişim göstermekte olduğu yapılan araştırmalarda karşımıza çıkmaktadır. Özellikle CMC döneminde tek oda olarak planlanan bekar işçi evlerinin, günümüzde dört ve altı arasındaki çeşitli sayılara sahip odanın birleşmesi ile bir ailenin yaşayacağı tek bir haneye dönüştürülmesi en belirgin örnek olmuştur. Bu bağlamda evli işçi evlerinde ise en belirgin dönüşümün, iki konutun birleşmesinden tek bir konutun oluşturulması, ıslak hacimlerin konut içerisine dahil edilmesi olduğu dikkati çekmektedir. Ustabaşı konutlarında ise, ıslak hacimlerin ve ek odanın konut içerisine dahil edilip, tek bir konuta kapsamında işlevlendirildiği tespit edilmiştir. Öte yandan mühendis evlerinde ise yukarıda bahsi geçen değişikliklerin olmadığı görülmektedir. Buradan da anlaşıldığı üzere, bu kategorideki konutların hacim ve işlevsel olarak bir aileye uygun tasarlanmış olduğu söylenebilir. Bu değişen duruma daha büyük ölçekten bakılacak olunursa, CMC dönemindeki konutların tasarımında ve yapımında kullanılan grid sistemin, günümüzde kullanıcılar tarafından yapılan değişikliklerden dolayı bozulduğu görülmektedir. 
Kullanıcı ihtiyaçlarının zaman içerisindeki değişimine çeşitli faktörler etki etmektedir. Kültürel, sosyal, ekonomik ve siyasi oluşumlardaki değişimler, yaşam şartlarına da etki etmektedir. Bu çalışmada da kullanıcı ihtiyaçlarının, alanların büyüklüklerine göre değişimi de etkilediği dikkati çekmektedir. Tek mekanlı konutlarda, şimdiki yaşam şartlarına uygun olabilmesi için yapılan değişiklikler çok fazla iken, bir çok odadan oluşan konutlarda değişimin gözlemlenmediği ya da çok dikkat çekici boyutta olmadığı görülmektedir. $\mathrm{Bu}$ bağlamda bu tip konut mimarisinin sonradan yapılan konut mimarisinde bir etkisi olmadığ gözlemlenmiştir.

\section{Kaynakça / References}

Anıl, Cemal (2011). 'CMC, Mini Bir Hükümet Gibiydi’. Lefkoşa: Yay. Haber Kıbrıs Gazetesi (14 Mart 2011).

Bağışkan, Tuncer (2013). 'Kıbrıs'ta Bakır Endüstrisinin Geçmişi'. Lefkoşa: Yay. Yenidüzen Gazetesi (06 Kasim 2013).

Bruce, J. L. (1937). 'The Swedish Cyprus Expedition'. Stockholm: Yay. Victor Petterson, pp. 205-232

Çağanağa, Vedat (2014). 'The Role of Copper Mine Lodging Houses on the Urban Development The Case of Lefke’. Lefke Avrupa Üniversitesi, Doktora Tezi, 2014.

CMC Arşiv Odası (2015). Lefkoşa: Yakın Doğu Üniversitesi Kütüphanesi.

Dağl1, Uğur Ulaş (1999). 'Kıbrıs Sokaklarında Mimariye, Yaşama ve Çevreye Dair', Yay. Işık Kitabevi.

Houssein, Y. (2013). 'How was the social life in Lefke during and after the CMC period', aktaran; V. Çağanağa, 'The Role of Copper Mine Lodging Houses on the Urban Development The Case of Lefke'. Lefke Avrupa Üniversitesi, Doktora Tezi, 2014

Lavender, D. (1962). 'The Story of Cyprus Mines Corporation'. California: Yay. The Huntington Library San Marino.

Sergil, K. (2012). 'How was the social life in Gemikonağl during the CMC period' (V. Çağanağa, Interviewer, 5 Mart 2012). 


\section{Sözlü Kaynaklar / Interviews}

Cemal Anıl ile Temmuz 2015 tarihinde gerçekleştirilen kişisel iletişim.

\section{İnternet Kaynakları / Web Sources}

nazimberatli.org/ow_userfiles/plugins/ifiles/Lefke\%20SEVGİLIM.pdf, pp: 4-6, 66

https://tr.instela.com/sanayi-devrimi--264830 (03.05.2017-18:50)

tr.wikipedia.org/wiki/Sanayi Devrimi (05.05.2017-21:42)

http://www.yeniduzen.com/Ekler/adres-kibris/130/kibris-ta-bakir-endustrisinin-gecmisi/850

$(07.05 .2017-23: 12)$

http://haberkibris.com/85f5830c-2011_03_14.html (09.05.2017-13:05) 